\title{
ODKUD ŘEČ \\ Herderovo hledání odpovědi na otázku po lidském, či božském původu řeči
}

\section{Olga Navrátilová}

V roce 1769 zveřejnila Berlínská akademie věd soutěžní otázku: „Jsou lidé schopni za předpokladu, že jsou ponecháni svým přirozeným schopnostem, vynalézt řeč? A jakými prostředky přišli sami k tomuto objevu?"1 Berlínské akademiky nevede v první řadě historický zájem, nýbrž otázka po vzniku kulturních fenoménů na pozadí lidské přirozenosti je pro sedmnácté a osmnácté století především otázkou po jejich povaze a zákonitostech. Jak známo, mladý Herder odpověděl svým Pojednáním o puvodu řeči (Abhandlung über den Ursprung der Sprache), s nímž soutěž vyhrál. Formulace otázky vyzývá autory k tomu, aby se snažili hledat důvody pro tvrzení, že řeč má svůj původ v lidské přirozenosti. Tomu také Herder ve svém pojednání dostál. Ti, kdo zastávají tezi o božském původu jazyka a mezi něž Herder počítá zejména Johanna Petera Süßmilcha, Boha antropomorfizují, ${ }^{2}$ nebot' si ho vposled představují jako rodiče, který učí své děti mluvit. ${ }^{3}$ Süßmilch tvrdí, že dokonalá, uspořádaná a krásná řeč musí být výtvorem úmyslného jednání rozumu. Současně se však lidský rozum může rozvíjet jen prostřednictvím řeči. Rozum tedy předpokládá řeč a řeč rozum. Abychom mohli z tohoto kru-

1 „En supposant les hommes abandonnés à leurs facultés naturelles, sont-ils en état d'inventer le langage? et par quels moyens parviendront-ils d'eux mêmes à cette invention?" C. Neis, Anthropologie im Sprachdenken des 18. Jahrhunderts. Die Berliner Preisfrage nach dem Ursprung der Sprache (1771), Berlin - New York 2003, str. 95.

2 J. G. Herder, Frühe Schriften. 1764-1772, Frankfurt a. M. 1981, FA 1, str. 809 (čes. překl. str. 97). Ve svém článku odkazuji na příslušné svazky Herderových spisů vydaných Deutscher Klassiker Verlag $(=F A)$. Odkaz na stranu v českém překladu Pojednání o puvodu řeči (J. G. Herder, Uměním k lidskosti, přel. J. Binder, Praha 2006), který je bohužel často nepřesný, uvádím v závorce. Pro citace užívám překlad vlastní.

3 Tamt., str. 727 n. (čes. překl. str. 35). 
hu vystoupit, je třeba postulovat vyšší původ řeči než lidský. ${ }^{4}$ Tímto postulátem však podle Herdera kruh není zrušen, nebot' měl-li člověk být schopen přijmout od Boha řeč, musel již užívat rozum. ${ }^{5}$ Uspořádanost lidské řeči, která se projevuje pravidelností gramatických pravidel a množstvím abstraktních výrazů a vztahů, je podle něj až výsledkem dlouhého vývoje, v němž rozvoj řeči podmiňuje rozvoj rozumu a naopak. Není to tedy božský rozum, který pro člověka vytvář́ řeč a předkládá mu ji jako hotové dílo, jak si to představoval Süßmilch, nýbrž řeč je produktem rozumu lidského a důsledkem jeho interakce se světem. O božském původu řeči je možno mluvit jen v tom smyslu, že řeč si člověk sice vytváří sám, jeho tvưrčí síla je však obrazem tvůrčí síly Boží. ${ }^{6}$ Člověk napodobuje Tvůrce všehomíru tím, že prostřednictvím řeči tvoří svůj vlastní, lidský svět.

Se svojí odpovědí z Pojednání o puvodu řeči přesto Herder není zcela spokojen (jako s ní nebyl spokojen ani jeho př́itel a kritik Johann Georg Hamann). ${ }^{7} \mathrm{~K}$ otázce po původu řeči se důkladněji vrací ve svém spise Nejstarši zpráva lidského rodu (Älteste Urkunde des Menschengeschlechts) z let 1774-1776, který je výkladem prvních kapitol biblické knihy Genesis. V něm se Herder vymezuje proti těm hypotézám o původu řeči, které ji vidí jako ,samorost lidské přirozenosti, sil a potřeb člověka““ ${ }^{8}$ Ty dospívají bud’ k rozpoznání pouhé „mrtvé schopnosti řeči, kterou člověk poznává jako živou pouze z výsledku a u níž zůstává věčná otázka: Jak se stala živou?“, nebo přenechávají vznik řeči „hře náhody“, čímž z ní činí něco, co je vůči člověku akcidentální. ${ }^{9}$ Zatímco v Pojednání Herder kritizoval představu, podle níž má Bůh při vzniku lidské řeči roli rodiče, který učí dítě mluvit, v Nejstarší zprávě se k ní sám hlásí. Ačkoli je třeba brát v potaz odlišný žánrový charakter obou spisů, naskýtá se otázka, zda theolog Herder svoji původní filosofickou pozici o ryze lidském původu řeči revidoval. Mým cílem v tomto článku je ukázat, že se nejedná o revizi, nýbrž o doplnění tezí obsažených v Pojednání o metafyzické před-

4 Tamt., str. 726 n. (čes. překl. str. 33 n.). Srv. J. P. Süßmilch, Versuch eines Beweises, daß die erste Sprache ihren Ursprung nicht vom Menschen, sondern allein vom Schöpfer erhalten habe, Berlin 1766, str. 15-17.

5 J. G. Herder, Frühe Schriften, str. 727 n. (čes. překl. str. 35).

6 Tamt., str. 809 (čes. př̀ekl. str. 97).

7 Srv. U. Gaier, Herders Sprachphilosophie und Erkenntniskritik, str. 146.

8 J. G. Herder, Schriften zum Alten Testament, Frankfurt a. M. 1993, FA 5, str. 519.

9 Tamt. 
poklady, které tvoří neopominutelný rámec Herderovy filosofie řeči. ${ }^{10}$ Jakkoli odtažitá a antikvovaná se otázka po božském, či lidském původu řeči dnešnímu čtenáři může zdát, umožňuje představit Herderovu ranou filosofii řeči ${ }^{11} \mathrm{v}$ širším kontextu jeho filosoficko-theologických postojů, který vykladači, již jinak poukazují na význam Herderova pojetí řeči pro další vývoj filosofie řeči, často opomíjejí. ${ }^{12}$

\section{Původ řeči podle Pojednání o původu řeči: Lidská řeč mezi řečí přírodní a božskou}

Ve svém Pojednání o pưvodu řeči se Herder vymezuje proti dvěma odlišným pojetím řeči. To první odvozuje původ lidské řeči z přírodní řeči

10 Tezi o neslučitelnosti Herderových postojů v obou spisech vyslovil Herderův životopisec Rudolf Haym. Tvrdí, že theolog Herder opouští v Nejstarší zprávě sekulární a filosofické pozice osvícenství, které zastával v Pojednání o původu řeči, ve prospěch bojovné náboženské apologetiky (R. Haym, Herder nach seinem Leben und seinen Werken dargestellt, I, Berlin 1880, str. 560). O sto let později chce Ulrich Gaier ukázat, že naopak také Pojednání obsahuje implicitní náboženský rozměr, který však zůstává vykladači zpravidla opomíjen. Herder podle něj v tomto spise odmítá „,antropomorfickou představu Boha jako učitele vyučujícího člověka řeči“, ale činí tak proto, aby mohl ukázat hlubší rozměr Božího působení v dějinách prostřednictvím uskutečňování lidskosti člověka (U. Gaier, Herders Sprachphilosophie und Erkenntniskritik, str. 146). Tento náboženský rozměr se ztrácí pod „leibnizovsko-estetickou slupkou“, kterou Herder podle svých slov v dopise Hamannovi musel volit, aby se přizpůsobil požadavkům Berlínské akademie věd (tamt., str. 77). Nejstarší zpráva tak podle Gaiera není přehodnocením dosavadních Herderových pozic, ale korekcí a doplněním toho, co zůstalo v Pojednání i v Herderových očích nedopracováno či zamlčeno (tamt., str. 164). Ve svém textu se přikláním k pozici Ulricha Gaiera, aniž bych ho však sledovala v jeho analýzách údajných kabalistických motivů obou spisů. Na rozdíl od něj se nebudu věnovat analýze náboženské dimenze Pojednání o pưvodu řeči, ale naopak ukáži, v jakém smyslu Herder i při výrazně odlišném způsobu výkladu svoje teze z tohoto spisu v Nejstarší zprávě podržuje a v jakém zároveň rozšiřuje.

11 K významu Herderova pojetí řeči pro další vývoj filosofie řeči i současnou diskusi viz zejména vlivný článek Charlese Taylora Význam Herdera (Ch. Taylor, The Importance of Herder, in: týž, Philosophical Arguments, Cambridge (MA) - London 1997, str. 79-99).

12 Tak např́iklad Michael N. Forster, podle nějž si Herderova filosofie uchovává svůj význam pro dnešek proto, že je v ní možno oddělit jeho víru v Boha a theologii, kterou s ním údajně z filosofických důvodů nemůžeme sdílet, od jeho filosofických náhledů (M. N. Forster, Herder's Philosophy, Oxford 2018, str. 14 n., 18, 39). To je zajisté v mnoha ohledech pravda, přesto je tím naše porozumění Herderově filosofii i jeho významu ochuzeno. 
zvîrat, jež má mimorozumovou, instinktivní a mechanickou povahu. ${ }^{13}$ Každý silný prožitek vyvolává v živé bytosti zvukový výraz, jenž na oplátku vyvolává prožitek v bytosti soucítící. Tato přírodní řeč vytváří svazek přírody založený na soucitu, který je tím užší, čím rodově blíže k sobě jednotliví tvorové mají, což dává vzniknout druhově specifickým zvîrecím řečem. ${ }^{14}$ Ani této prrírodní řeči nechybí úplně odkazující a sdělná funkce: Křik odkazuje na určitou situaci (nebezpečí, slasti apod.) a umožňuje ostatním tvorům adekvátně k ní přizpůsobit své chování. Podle Herdera by však bylo chybou chápat tuto řeč jako řeč ve vlastním slova smyslu. Nejenže je jí vlastní malá míra rozlišenosti, ale právě tato malá míra rozlišenosti je dána tím, že jí chybí to podstatné, co konstituuje řeč lidskou: pochopení znaku jakožto znaku. Ti, kdo hledají původ lidské řeči v řeči zviŕrat - což jsou pro Herdera v Pojednání v první řadě Condillac a Rousseau -, ${ }^{15}$ se tak dostávají do kruhu: ${ }^{16}$ předpokládají to, co teprve chtějí odvodit, totiž slovo jakožto znak. ${ }^{17}$ Lidská řeč podle Herdera uchovává funkce řeči zvîrecí, ale na kvalitativně odlišné úrovni: z výkřiku se stává artikulované slovo a svazek založený na soucitu je proměněn ve svazek založený na logu.

Zatímco zastánci zvî́recího původu lidské řeči redukují podle Herdera člověka na zvîre, přívrženci názoru o božském původu řeči jej úplně vyčleňují z říše přírody. Vycházejí z pozdního stádia vývoje řeči, pro něž je charakteristická vysoká míra abstrakce, substantivizace a systematizace, a ztrácí ze zřetele vazbu řeči na smyslovost a představivost. Jak již bylo řečeno, zastánci názoru o božském původu řeči vycházejí podle Herdera z představy toho, jak se děti učí řeč od rodičủ. Jenže ani v tomto případě se děti neučí řeč jinak než tak, že ji současně ,,spoluvynalézají“, tedy že pochopí její princip a v souladu s ním řeč vlastně znovu pro sebe vytvářejí. ${ }^{18}$ Předávat řeč jako systém znaků je možné jen za podmínky,

13 J. G. Herder, Frühe Schriften, str. 707 n. (čes. překl. str. 19).

14 Tamt., str. 698 n. (čes. překl. str. 12 n.).

15 Srv. É. B. Condillac, Esej o pưvodu lidského poznání, přel. J. Otáhalová-Popelová, Praha 1974, str. 133-213. Rousseauovy názory ohledně původu jazyka čerpá Herder z jeho Rozpravy o puvodu nerovnosti mezi lidmi, protože Esej o původu jazyků v té době ještě nebyla zveřejněna.

16 Tohoto kruhu si je Rousseau, který sám reaguje na Condillaca, vědom, a proto nakonec nechává v Rozpravě o původu nerovnosti otázku po vzniku řeči nerozřešenou. Srv. J.-J. Rousseau, Rozpravy, přel. E. Blažková et. al., Praha 1978, str. 97-102.

17 J. G. Herder, Frühe Schriften, str. 710 (čes. překl. str. 21).

18 Tamt., str. 727 (čes. překl. str. 35). 
že recipient chápe znak jako znak. ${ }^{19}$ Tyto znaky ale nepadají z nebe, nýbrž jsou, jak bude ukázáno vzápětí, produktem souhry představivosti, pozornosti a reflexe.

Oproti těm, kdo původ lidské řeči odvozují od zvî́recí formy sebevýrazu a komunikace, tak Herder zdůrazňuje neodvoditelnost lidské řeči z pouhých zvîrecích dispozic: řeč je „orgánem rozumu“ ${ }^{20}$ který je bytostně lidský. Oproti zastáncům názoru o božském původu řeči naproti tomu Herder trvá na úzkém propojení rozumu s dalšími mohutnostmi duše. Rozum, jenž si dává výraz v řeči, není schopností oddělenou od nižších mohutností duše a přidanou k nim jakoby zvnějšku, nýbrž z těchto mohutností vyrůstá a současně se do nich promítá: je jejich celkovou „dispozicí“ a sjednocuje je v jediném zaměření. ${ }^{21} \mathrm{~V}$ člověku, stejně jako v ostatních tvorech, působí jen jedna síla, která se vyjadřuje v množství svých projevů, a skutečnost, že tyto projevy oddělujeme, srovnáváme a třídíme do jednotlivých kategorií, je teprve výsledkem abstrahující činnosti našeho rozvažování, které - jakkoli je nezbytné není schopno uchopit je v jejich jednotě. ${ }^{22}$ Pro Herdera se proto smyslovost člověka i povaha jeho představivosti bytostně liší od smyslovosti a představivosti jiných tvorů, jakkoli jsou v mnohém analogické: svým uzpůsobením jsou $\mathrm{v}$ př́ípadě člověka zaměřeny $\mathrm{k}$ řeči. ${ }^{23}$ Tuto celkovou dispozici nazývá Herder v Pojednání o puvodu řeči „Besonnenheit“, kterou český překladatel překládá jako „vědomí“24 a jejímž hlavním rysem je reflexivita: ${ }^{25}$ Člověk je tvor, který nejenže „,poznává, chce a působí, nýbrž také ví, že poznává, chce a působí“. ${ }^{26}$ „Besonnenheit“, vědomí, pak Herder, jak bude ukázáno dále, odlišuje od „Besinnung“, aktu uvědomění si.

19 Tamt.

20 Tamt., str. 733 (čes. překl. str. 39).

21 Tamt., str. 717 (čes. překl. str. 27).

22 Tamt., str. 718 (čes. překl. str. 28).

23 Srv. tamt., str. 717 (čes. překl. str. 27). Už i uspořádání smyslů je proto u člověka zaměřeno $\mathrm{k}$ řeči. To platí i pro představivost, která není úzce vázána jen na jednu či malý počet funkcí nutných k vykonávání instinktivně určených činností (např. stavbu včelích buněk), nýbrž je ve své kombinatorické schopnosti svobodná. Srv. tamt., str. 715 n. (čes. př̀ekl. str. 26 n.).

24 Srv. J. G. Herder, Uměním k lidskosti, str. 29.

25 Srv. týž, Frühe Schriften, str. 722 (čes. překl. str. 31), kde Herder chápe pojmy „Besonnenheit“ a „Reflexion“ synonymně.

26 Tamt., str. 719 (čes. překl. str. 28). 
Jak tedy vzniká podle Herdera řeč? Řeč je produktem souhry duševních sil člověka pod vedením rozumu. Podmínka jejího vzniku je dvojí: (1) jednak vyčlenění charakteristického znaku (Merkmal), který umožňuje strukturovat proud vnímání do celků zahrnujících v sobě jednotu a mnohost a včleňuje je do vnitřního duševního světa člověka, tedy vnitřní slovo, (2) jednak přiřazení vnějšího znaku (Zeichen), primárně zvuku, tomuto charakteristickému znaku, tedy vnější slovo. ${ }^{27}$ I když první krok je podmínkou druhého, oba kroky nejsou následné, nýbrž jdou podle Herdera pospolu.

\subsection{Vnitřní slovo jako podmínka vzniku řeči}

Jak bylo řečeno, člověk se podle Herdera liší od zvîrete tím, že všechny jeho duševní mohutnosti, kterými si přivlastňuje vnější svět, jsou pod vedením rozumu zaměřeny ke vzniku řeči. Proces smyslového vnímání a s ním související práce představivosti, jejímž produktem je předmětný pól tohoto vnímání, „obraz“, jsou u člověka díky jeho schopnosti reflexe vyzdviženy na rovinu vědomí, které je spojeno se schopností zaměřit pozornost (Aufmerksamkeit), ${ }^{28}$ a to dvojím směrem. (1) Reflexivita jednak umožňuje zaměřit pozornost na samotný proces vnímání, a tím i na ni samu: z celého „oceánu prožitkư“ pozornost vyčleňuje a podržuje jednu ,vlnu“ a současně si svoje zaměření uvědomuje. ${ }^{29}$ To jí umožňuje nebýt pouze pasivně vydána všanc podnětům, které ji přitahují různými směry, nýbrž aktivně se zaměřovat a samu sebe řídit. (2) Toto reflexivní zaměření pozornosti se proto současně promítá do způsobu, jak se pozornost vztahuje k předmětnému pólu těchto prožitků, k „obrazům“ či představám: ze „snu obrazü“, které jí přinášejí smysly, se „usebírá do momentu bdění“, prodlévá u jednoho obrazu a činí z něj charakteristický znak (Merkmal) ${ }^{30}$ vnímaného předmětu (například bečení v případě ovce). ${ }^{31}$ Vnímající tak pouze nepoznává (erkennt) ,jasně a živě“ (klar

27 Toto terminologické odlišení není v Pojednání důsledné, ačkoli věcný rozdíl je zřetelný. K odlišení „Merkmal“ a „Zeichen“ (či „Symbol“) srv. J. G. Herder, Ideen zur Philosophie der Geschichte der Menschheit, Frankfurt a. M. 1989, FA 6, str. 348-350.

28 Schopnost zaměřit pozornost a reflexi spojuje již É. B. Condillac, Esej o pưvodu lidského poznání, str. 63.

29 J. G. Herder, Frühe Schriften, str. 722 (čes. překl. str. 31).

30 Do češtiny bohužel souvislost slov „Aufmerksamkeit“ (pozornost), „,merken“ (povšimnout si), „Merkmal“ (charakteristický znak) a „sich merken“ (zapamatovat si) není převoditelná.

31 J. G. Herder, Frühe Schriften, str. 722 (čes. překl. str. 31). 
und lebhaft) jednotlivé vlastnosti tohoto předmětu, ale pro sebe rozpoznává, uznává či potvrzuje (anerkennt) jednu z nich jako tu rozhodující. Ta mu zastupuje vnímaný předmět, sjednocuje mnohost jeho aspektů pod aspekt jediný, umožňuje jeho odlišení od ostatních i jeho opětovné rozpoznání.

Vyčlenění charakteristického znaku je tak na jedné straně úzce spojeno se smyslovým vnímáním a prací představivosti, na straně druhé je však genuinním aktem myšlení, aktem diferenciace a sjednocení. Jeho prostřednictvím člověk strukturuje svět, který se dává jeho smyslům a který on tímto proměňuje ve svět vnitřní. Proto Herder označuje tento akt jako „první soud duše“ (das erste Urteil der Seele), jímž vzniká „zřetelný pojem“ (deutlicher Begriff). ${ }^{32}$ Na rozdíl od výše uvedených „jasně a živě“ vnímaných vlastností je charakteristický znak ,zrretelným pojmem“ proto, že v něm duše spojuje ideu se znakem, který umožňuje tuto ideu podržet a znovu vyvolat (např́íklad bečení jakožto znak s ideou ovce ve starém př́kladu z Kratyla,${ }^{33}$ který užívá i Herder) ${ }^{34}$ Tento pojem nevystihuje věc, jak je o sobě, nýbrž je způsobem, jímž si člověk věc přivlastňuje a začleňuje ji do svého vnitřního světa. V návaznosti na tradici nazývá Herder tento pojem ,slovem duše“35 či „vnitřním slovem“. Toto vnitřní slovo, které Herder později ve spise $O$ poznávání a pocit’ování lidské duše charakterizuje v aluzi na Gn 2,19 jako „nazírající, božský dar označování“, 36 je intrasubjektivní podmínkou vzniku řeči jako prostředku mezilidské komunikace: „První charakteristický znak, který uchopuji, je pro mě slovem upamatování a pro jiné slovem sdělení!“ (Das erste Merkmal, das ich erfasse, ist Merkwort für mich und Mitteilungswort für Andre!). ${ }^{37}$

K rozlišení mezi ,jasnými a živými““ představami a „žretelným“ pojmem, který vzniká vyčleněním charakteristického znaku, na němž se podílí reflexe, se Herder vrací ještě později v Pojednání o puvodu řeči, a sice v oddíle, v němž dává v návaznosti na Étienna Bonnota de Condillaca $^{38}$ do souvislosti pamět' a řeč. Zatímco pro zvî́rata je charakteris-

\footnotetext{
32 Tamt.

33 Platón, Crat. 423c.

34 Tamt., str. 724 (čes. překl. str. 32).

35 Tamt., str. 722 (čes. překl. str. 31).

36 J. G. Herder, Schriften zu Philosophie, Literatur, Kunst und Altertum. 1774 1787, Frankfurt a. M. 1994, FA 4, str. 358.
}

37 Týž, Frühe Schriften, str. 735.

38 Srv. É. B. Condillac, Esej o puvodu lidského poznání, str. 59-63. 
tická pouhá „smyslová pamět"“, která může v mnohém předčit i smyslovou pamět' lidskou, u člověka je pamět' spojena s reflexí, a tedy i s řečí. Zvîrecí i lidská pamět’ totiž pouze neuchovává, nýbrž spojuje. Jen v případě člověka jsou však ,,smyslové, jasné, živé představy“ spojovány pod „zřretelnou jednotu“, jednotu pojmu, a tak uchovávány. ${ }^{39}$ Nad posloupností jeho idejí vládne „Besonnenheit“, a to - byt' sotva patrně - i v tom „nejsmyslovějším stavu“, v němž se člověk kdy nalézal. ${ }^{40}$

Postulováním vnitřního slova jako nezbytné podmínky každé řeči odpadá problém, který řeší Rousseau, totiž jak přejít ve vývoji řeči od přirozených znaků (křik, napodobování situace pomocí gest) ke znakům konvenčně ustaveným a od znaků vyjadřujících celek jedinečné situace k obecným jménům. ${ }^{41}$ Každé vyčlenění charakteristického znaku je aktem rozumu a projevem odstupu od jedinečné situace, každý znak je tedy již něčím obecným. Pochopí-li člověk znak jako znak či slovo jako slovo, je přechod od přirozených ke konvenčně ustaveným znakům více méně plynulý. Rousseau ve snaze o objasnění původu řeči kapituluje proto, že není schopen vystoupit z kruhu, na který naráží - i když v modifikované podobě - také Süßmilch, ${ }^{42}$ totiž že ke vzniku řeči je třeba rozumu a k rozvoji rozumu je třeba řeči. Základní chybou obou podle Herdera je, že v člověku předpokládají jakousi zcela neaktualizovanou schopnost řeči či rozum, který je v čiré potenci, čímž se nevyhnutelně dostávají do výše uvedeného kruhu. ${ }^{43}$ Herder naproti tomu předpokládá, že člověk je celkovou dispozicí svých sil zaměřen $\mathrm{k}$ řeči, „,Besonnenheit“ je vždy již také aktivita určující náš vztah ke světu (více k tomu oddíl 1.5).

39 J. G. Herder, Frühe Schriften, str. 772 n. (čes. překl. str. 69 n.).

40 Tamt., str. 773 (čes. př̀ekl. str. 69 n.).

41 Srv. J.-J. Rousseau, Rozpravy, str. 99-102.

42 Süßmilch proto v Rousseauovi podle svých slov nachází spojence, nebot' oba, byt' nezávisle na sobě, došli ke stejnému kruhu mezi rozumem a řečí jako vzájemně na sebe odkazujícím podmínkám (J. P. Süßmilch, Versuch eines Beweises, str. 12 n., 117-123).

43 Jak podotýká Ulrich Gaier v komentáři k Herderovým raným spisům, Süßmilchovo pojetí vlohy k řeči je blízké pojetí Herderovu (je mohutností ve smyslu síly, která jen musí být rozvinuta) a Herder zde bojuje proti „strašidlu, které sám vymyslel“ (J. G. Herder, Frühe Schriften, str. 1307). K tomu je možné dodat, že Süßmilchův problém je spíše v tom, že řeč chápe jako účelně vytvořený krásný a dokonalý systém, který Bůh vytvořil nezávisle na člověku, naproti tomu podle Herdera působí Boží tvůrčí moc, jejímž výsledkem je řeč, imanentně v nitru člověka. 


\subsection{Přiřazení vnějšího znaku}

Bečení ovce a další zvuky přírody se podle Herdera přirozeně nabízejí jako první charakteristické znaky, ${ }^{44}$ což je dáno zejména prostředkujícím postavením, které má sluch mezi ostatními smysly. ${ }^{45}$ To je také důvod, proč zvuky jakožto vnější znaky převážily při vzniku řeči nad gesty a řeč tak dostala zvukovou podobu. První přiřazení vnějšího slova slovu vnitřnímu je proto $\mathrm{v}$ případě charakteristických znaků, které mají podobu tónů, velmi plynulé. Příroda sama k člověku mluví a člověk tuto řeč př́írody transformuje ve svoji řeč, která se však od přírodní řeči zviŕat kvalitativně odlišuje: ze zvuků, jimiž všichni živí tvorové dávají výraz svým pocitům a které na rozdíl od zrakových podnětů pronikají podle Herdera hlouběji do lidské duše a lépe v ní ulpívají, se na základě „soudu duše“ stávají charakteristické znaky. Jejich vyslovení proto není pouhou nápodobou slyšeného zvuku, nýbrž slovem, vyjádřením pojmu či myšlenky. ${ }^{46}$ Mezi bečením, které vydává ovce, a zvukem „béé“, který vydává při pohledu na ovci dítě, je tak zásadní rozdíl: jen ten druhý je slovem. ${ }^{47}$ Jakkoli je pro Herdera $\mathrm{z}$ důvodů uvedených dále důležité ukázat, že zvuková podoba slov nevznikla na základě pouhé konvence, ${ }^{48}$ tento kvalitativní přerod řeči přírody $\mathrm{v}$ řeč lidskou, zvuku ve slovo, otevírá v dalším vývoji řeči prostor konvenčnímu ustavení vnějších znaků. V případě řeči ve stavu zrodu je však díky zvukové povaze prvních charakteristických znaků propojení charakteristického znaku jakožto vnitřního slova a znaku jako slova vnějšího, určeného pro komunikaci s druhými i duše se sebou samou, velmi úzké.

Herder však musí vyřešit otázku, jak přiřadit zvuky jakožto znaky těm představám, které přinášejí jiné smysly než sluch: „Ne všechny předměty znějí, odkud tedy vzít slova (Merkworte), jimiž je duše pojmenovává?“449 Východiskem pro Herderovu odpověd’ je jeho teze o jednotném kořeni smyslového vnímání. Jednotlivé smysly jsou projevem jedné síly, jejímž

\footnotetext{
44 J. G. Herder, Frühe Schriften, str. 734 (čes. překl. str. 40).

45 Tamt., str. 746-750 (čes. překl. str. 50-52).

46 Srv. tamt., str. 724 (čes. překl. str. 33), 730 n. (čes. překl. str. 37 n.), 741 n. (čes. překl. str. 46).
}

47 Tomu nasvědčuje i skutečnost, že artikulace zvuků vydávaných zvîraty má v různých jazycích svoji ustálenou podobu, přičemž se tyto ustálené podoby liší.

48 Jakkoli současně platí, že vůči předmětu, jejž vnější slovo označuje, je přiřazení znaku arbitrární. Srv. J. G. Herder, Ideen zur Philosophie der Geschichte der Menschheit, str. $348 \mathrm{n}$.

49 Týž, Frühe Schriften, str. 742 n. (čes. překl. str. 47). 
prostřednictvím člověk jakožto smyslová bytost interaguje se světem. Smyslové vnímání pak má svoji subjektivní, pocitovou stránku - smysly jsou způsoby, jak duše pocit'uje („Gefühlsarten der Seele“" ${ }^{50}$ - a stránku předmětnou - smysly jsou zpơsoby, jak si duše představuje (,Vorstellungsarten der Seele“) ${ }^{51} \mathrm{~V}$ rané fázi vývoje člověka, at' už na rovině rodu nebo jednotlivce, je tato sensitivita ještě nerozlišená a jednotlivé počitky splývají dohromady v nediferencovaný temný pocit, stejně jako splývají i jednotlivé představy. Člověk se teprve postupně učí používat jednotlivé smysly a odlišovat jednotlivé představy, zároveň však dochází mezi jednotlivými smysly k nepozorované výměně (máme např́ílad za to, že představu trojdimenzionálního prostoru nám přináší zrak, ten si ji ale podle Herdera pouze vypůjčil od smyslu ranějšího, od hmatu). Tato výměna také umožňuje přiřazení tónů jiným než zvukovým představám. V počátcích individuálního i rodového vývoje člověka k sobě mají pocit a představa, subjektivní a předmětný pól smyslového vnímání velmi blízko: představy, které se teprve postupně vyčleňují z jednoty vnímání, jsou doprovázeny silnými pocity. Pocit pak podle zákona, jímž se řídí řeč přírody, vyvolává zvukový výraz. Jako příklady slov, které vznikly tímto způsobem, uvádí Herder „,tvrdý“ (hart), „,měkký“ (weich), „hladký“ (glatt) či „hořký“ (bitter). Ta všechna „znějí, jako by je člověk cítil““.52 Jsou tedy zvukomalebná ne v tom smyslu, že napodobují zvuky př́rody, nýbrž v tom smyslu, že jejich zvuk vyjadřuje pocit, který doprovází představu, jež se s nimi pojí (tak je tomu například i u slova „blesk“, Blitz, které dává výraz pocitu při pohledu na náhlé ozáření oblohy, jež zmizí ještě dřív, než na ně člověk stačí zaměřit pozornost).$^{53}$ Svůj postoj k otázce, odkud se berou artikulovaná slova pro jiné než zvukové představy, tak Herder shrnuje do odpovědi, že nejsme nic jiného než „myslící sensorium commune“" ${ }^{54}$ Tím je ve zkratce vyjádřen způsob vzniku řeči: předmětný pól smyslového vnímání, představy, myšlení rozlišuje v charakteristické znaky, čímž vzniká vnitřní řeč. Tyto představy jsou díky jednotě smyslového vnímání doprovázeny pocity, které nacházejí výraz ve zvucích, a ty se prostřednictvím myšlení přetvářejí ve znaky vnější, vnější řeč. 55

50 Tamt., str. 746 (čes. překl. str. 49).

51 Tamt., str. 744 (čes. překl. str. 48), 746 (čes. překl. str. 49).

52 Tamt., str. 746 (čes. překl. str. 49).

53 Tamt., str. 745 n. (čes. překl. str. 49).

54 Tamt., str. 743 n. (čes. překl. str. 48).

55 Tamt., str. 746 (čes. překl. str. 49 n.). 


\subsection{Další rozvoj řeči}

Vyčlenění charakteristického znaku je prvním aktem rozumu a přiřazení zvuku k tomuto charakteristickému znaku je prvním slovem lidské řeči. Herder v Pojednání sice rozlišuje mezi rozumem ${ }^{56}$ a řečí, jejich vzájemná vazba je však úzká a jejich vývoj vzájemně podmíněný. Řeč je podle něj ,„přirozeným orgánem“ 57 či „,smyslem“ ,58 jejž si rozum jakožto vnitřní síla duše vytváří. Je „vnějším rozlišovacím znakem“ lidského rodu, zatímco rozum je znakem vnitřním. ${ }^{59}$ Rozum se nemůže rozvíjet bez řeči a řeč bez rozumu. $V$ polemice se stoupenci božského původu řeči klade Herder důraz na to, že jak rozum, nakolik je organizující silou lidské duše, tak řeč jakožto její orgán podléhají vývoji a současné pokročilé stádium rozvoje rozumu a řeči nelze anachronisticky promítat do jejich počátků. ${ }^{60}$

Prostřednictvím řeči rozum nejenom strukturuje svět a přivlastňuje si jej, nýbrž současně v řeči (a tedy i ve světě) dává výraz sám sobě. Vytčené charakteristické znaky smyslově vnímaných věcí na jedné straně rozumu dodává smyslovost a představivost, na straně druhé jsou zároveň jeho myšlenkami, produktem jeho soudící moci (později v Metakritice Herder, aby vyjádřil tuto jednotu, mluví o „Denkbilder“).$^{61}$ Jak bylo řečeno, je vytčení charakteristického znaku prvním „soudem“ rozumu, aktem diferenciace i sjednocování, jímž rozum něco vyčleňuje a současně vztahuje k celku, zasazuje do sítě vztahů. Proto může Herder říci, že spolu s prvním „slovem duše“ byla vynalezena celá lidská řeč. ${ }^{62}$ Řeč není ani ve svých počátcích pouze souborem jednotlivých slov, ale vždy také systémem, celkem, jenž se postupně vnitřně rozvíjí a diferencuje spolu s tím, jak se rozvíjí lidská schopnost pojmenovávat, tedy proměňovat

56 Zdá se,že v Pojednání Herder používá pojem „Vernunft“ a „Verstand“ poměrně synonymně. Není tomu tak ale ve všech jeho spisech (srv. např. J. G. Herder, Frühe Schriften, str. 717, 733 a 809). Rozdíl mezi nimi činí nejen v pozdní Metakritice ke Kritice čistého rozumu, zde pochopitelně v návaznosti na Kanta, ale také již v raných Fragmentech k novější německé literatuře (srv. tamt., 424 n).

57 Tamt., str. 733 (čes. překl. str. 39).

58 Tamt., str. 809 (čes. překl. str. 97).

59 Tamt., str. 732 n. (čes. překl. str. 39).

60 Srv. např. tamt., str. 725-727 (čes. překl. str. 33 n.).

61 J. G. Herder, Schriften zu Literatur und Philosophie. 1792-1800, Frankfurt a. M. 1998, FA 8, str. 418.

62 Týž, Frühe Schriften, str. 723 (31), srv. tamt., str. 733 (čes. překl. str. 39). 
podněty přinášené smysly a zpracované představivostí ve strukturovaný vnitřní svět, jemuž rozum ukládá svůj řád. ${ }^{63}$

Při rozšiřování schopnosti pojmenovávat, jakkoli ta se pochopitelně neobejde bez rozlišujícího soudu rozumu, hrají významnou roli smyslovost a fantazie. Jednota smyslového vnímání, která umožňuje přenos a výměnu mezi jednotlivými smysly, umožňuje současně rozšiřovat horizont toho, co je vyslovitelné, prostřednictvím metafory: „V počátcích metafory bylo nutkání (Drang) mluvit...".64 Představa z jedné oblasti smyslovosti tak může být vyjádřena prostřednictvím slova spojeného s představou z oblasti jiné, a to díky blízkosti pocitů, které je doprovázejí, a síle fantazie, která tato spojení uskutečňuje. ${ }^{65}$ Herder píše o „smělých metaforách v kořenech slov" 66 archaických řečí (kam řadí například hebrejštinu), pomocí tohoto přenosu je ale také možné vysvětlit, proč mluvíme o měkkých barvách, ostrých rysech či kulaté a plné chuti vína. Rož̌iřování schopnosti pojmenovávat, jež umožňuje metaforický přenos významu, stejně jako množství synonym jsou podle Herdera typické zejména pro řeči v počátcích jejich rozvoje, další vývoj řeči je postupem $\mathrm{k}$ její systematizaci a racionalizaci. Tyto rané řeči na jednu stranu teprve hledají slova, na straně druhé jich v některých oblastech mají nadbytek, a je pro ně tedy typické množství synonym, která teprve čekají na třídící práci rozumu. ${ }^{67}$

Smyslový původ mají také slova označující abstrakta nejrůznějšího druhu, jak Herder ukazuje na př́kladech pojmů „duch“, „duše“, „,svatý“ či „hněv““ ${ }^{68}$ Lidský rozum nemůže existovat bez abstrakce, píše Herder, současně však k žádné abstrakci nedochází bez řeči ${ }^{69}$ Rozum strukturuje a třídí smyslově přístupný svět prostřednictvím všeobecných pojmů a od toho, co je smyslově přístupné, postupuje k tomu, co je smyslově nepřístupné. V rané fázi vývoje rozumu bylo pro člověka obojí, viditelné i neviditelné, ještě neoddělitelně spojeno (dech s duchem, pohyb chřípí s hněvem apod.), a tak tomu bylo i v řeči. Řeč nemá žádné abstraktum, k němuž by se nedostala ,prostřednictvím tónu

63 Srv. týž, Schriften zu Literatur und Philosophie, str. 509. Týž, Frühe Schriften, str. 755 (čes. překl. str. 56).

65 Tamt., str. 754 (čes. překl. str. 55).

66 Tamt., str. 752 (čes. překl. str. 54).

67 Tamt., str. 755-758 (čes. překl. str. 57-58).

68 Tamt., str. 758 (čes. překl. str. 58).

69 Tamt., str. 761 (čes. překl. str. 61 n.). 
a pocitu“ “ ${ }^{70}$ Abstraktní pojmy jsou pochopitelně výrazem rozumu, rozum je však ustavuje přenosem původních smyslových významů slov, a sice prostřednictvím ,abstrakce, důvtipu, fantazie, podobenství, analogie atd.“. ${ }^{71}$ Rozum tak nemá žádné abstraktum předtím, než pro něj vynalezne (vnější) slovo.

Jak bylo řečeno, je rozšiřování schopnosti pojmenovávat, které je rozšiřováním lidského světa, doprovázeno strukturováním tohoto světa, jeho racionalizací, která se odráží v gramatice. První charakteristické znaky, a tedy i první slova poskytují člověku zvuky prrírody: „Od každé zvučící bytosti zaznívalo její jméno: lidská duše vtiskla těmto zvukům svůj obraz, myslela je jako charakteristické znaky.“72 Toto jméno vyjadřovalo ještě obojí, jednání i subjekt tohoto jednání, a kolísalo mezi obojím. ${ }^{73}$ Slovesa jsou podle Herdera původnějšími slovy než substantiva (a vůbec nejpůvodnějšími slovy jsou citoslovce) ${ }^{74} \mathrm{k}$ vyčlenění subjektu a rozvinutí původního jména vyjadřujícího činnost do subjekt-predikátové věty je třeba dalšího analyzujícího soudu myšlení, který z účinku usuzuje na př́íčinu, a tak současně oba rozlišené členy uvádí do kauzálních vztahů. ${ }^{75} \mathrm{~V}$ této základní struktuře věty, která má svůj původ ve slovesu, k němuž rozum ustavuje subjekt, se odráží sama povaha rozumu jakožto síly, která si dává výraz ve svých účincích. ${ }^{76}$ Skutečnost, že člověk v rané fázi svého vývoje vidí celou přírodu jako oduševnělou, se zakládá v tom, že do ní promítá sám sebe jakožto subjekt jednání, jak o tom svědčí právě struktura řeči. Tato projekce dává vzniknout také základním mluvnickým kategoriím, jako je rod sloves uvádějící celou prrírodu do vztahů činnosti a trpnosti, lásky a nepřátelství nebo mužský a ženský rod podstatných jmen. Postupná substantivizace řeči a vznik obecných pojmů na základě další práce s charakteristickými znaky a jejich utřídění do jednotlivých kategorií, vznik slovesných časů a vůbec další systematizace řeči ${ }^{77}$ jsou projevem

\footnotetext{
70 Tamt., str. 758 (čes. překl. str. 59).

71 Tamt.

72 Tamt., str. 737 (čes. překl. str. 42).

73 Tamt., str. 737 (čes. překl. str. 42 n.).

74 Tamt. a dále tamt., str. 780 (čes. překl. str. 75).

75 Tamt., str. 736 n. (čes. překl. str. 42).

76 Tuto souvislost sleduje Herder zejména v pozdní Metakritice, kde se zabývá i dalšími kategoriemi myšlení vyjádřenými v řeči. Srv. týž, Schriften zu Literatur und Philosophie, str. 406-408.
}

77 Srv. týž, Frühe Schriften, str. 762-765 (čes. překl. str. 62-64). 
abstrahující činnosti rozumu, která na jedné straně dále strukturuje svět a činí jej uchopitelným, na straně druhé si od něj zjednává čím dál větší odstup. $^{78}$

\subsection{Potence a aktualizace tvorby řeči: Besonnenheit a Besinnung}

Vyčlenění charakteristického znaku a přiřazení znaku vnějšího, zvuku, jsou nezbytnými kroky při tvorbě řeči. Obojí je výkonem člověka, produktem souhry jeho mohutností. To platí podle Herdera i tehdy, když se děti učí řeč od rodičů. Rodiče dětem tvorbu řeči pouze „ulehčuji“ tím, že je ,prostřednictvím určitých slovních znaků upozorňují na rozdíly věcí“.79 To podstatné, totiž „rozumět slovu jakožto slovu“, je však přenecháno na dítěti samotném a toto rozumění je projevem jeho rozumové povahy, jež je mu vlastní jakožto př́íslušníku lidského rodu. ${ }^{80}$ Proto je také možné naučit řeč dítě, a ne papouška či psa. ${ }^{81}$

Herder nijak nepopírá význam druhých při této výuce, jak je patrné zejména z druhé části jeho Pojednání o pưvodu řeči. Řeč umožňuje udržení kontinuity a jednoty při neustálé změně a vývoji nejen v případě duševního života jednotlivce (který by bez ní ani nebyl možný), ale tutéž funkci plní i napříč generacemi jak u jednotlivých národů, tak vposled i celého lidstva. ${ }^{82}$ Mateřská řeč člověku otevírá svět. Je způsobem, jak se jej učíme nejen vidět, ale také cítit. Spolu s ní se nám předává celý „způsob myšlení“ rodičů ${ }^{83}$ tedy i celá kultura, do níž se rodíme a kterou řeč vůbec umožňuje vytvářet a prostředkovat. Když však půjdeme zpětně po tomto řetězci tradice a postupného rozvoje řeči až k prvnímu článku, můžeme se ptát, odkud se vzal. Jak došlo k aktualizaci lidské schopnosti tvorby řeči?

78 Svoji teorii vývoje řeči představuje Herder ve Fragmentech. Analogicky ke koloběhu lidského života a vůbec všeho živého prochází i řeč stádii od dětství až ke stáří, přičemž se vyvíjí od podoby smyslové přes básnickou a prozaickou až po filosofickou. Srv. tamt., str. 181-184.

79 Tamt., str. 727 (čes. překl. str. 35).

80 Tamt. Srv. také tamt., str. 719 (čes. překl. str. 29).

81 Srv. tamt., str. 732 (čes. překl. str. 38).

82 Řeč a s ní spojenou kulturu, která si svoji jednotu udržuje jen prostřednictvím neustálé změny, tak Herder označuje jako „progresivní celek“ či „progresivní jedno“. Tím je vposled i lidstvo samo v kontinuitě své kultury. Srv. tamt., str. 800 (čes. překl. str. 90).

83 Tamt., str. 786 n. (čes. překl. str. 79 n.). 
Herder v první řadě odmítá, že by lidská uzpůsobenost k řeči byla kdy čirou potencí ${ }^{84}$ at' už v případě vývoje jednotlivce, nebo lidstva jako celku. „Besonnenheit“, která je vlastní člověku jako příslušníku rodu a je podmínkou vzniku řeči, je dispozicí všech jeho duševních sil, jako je smyslovost, představivost atp. Proto je v působení těchto sil vždy již nějakým způsobem aktivní, byt' třeba takřka neznatelně. ${ }^{85}$ I předřečovost člověka je již nějakým způsobem řečová a vše v člověku spěje k okamžiku, kdy se z „Besonnenheit“" stává „Besinnung“, ${ }^{86}$ kdy dojde k uvědomění si prvního znaku. Tento okamžik má v sobě zajisté něco zázračného - stejně jako třeba okamžik zplození - a Herder při něm připouští i působení Boží prozřetelnosti, ${ }^{87}$ ta je však pro něj totožná s působením zákonů, které řídí organický rozvoj př́rody. 88

Vzhledem k tomu, že pro vznik řeči je podstatná souhra všech duševních sil člověka, klade Herder tento vznik do doby, kdy podle něj v lidské duši ještě vládla jejich jednota, vyrovnanost a současně nerozvinutost, která umožňovala vzájemnou výměnu (doba, která se v určitém smyslu opakuje ve vývoji každého jednotlivce v době, kdy se jakožto dítě učí mluvit): „Čím méně jsou duševní síly ještě rozvinuty a každá vycvičena pro svoji vlastní sféru, tím silněji působí všechny dohromady, tím niternější je střed jejich intenzity.“ Duše, která ještě žije v těsném spojení s prrírodou, ,v kruhu potřeb, nebezpečí, vtíravých nutností“, a jež má „sdostatek smyslovosti a současně instinktu“, ,,pocit’uje celý hlahol a všechny projevující se charakteristické znaky živoucí přírody tak plně, jako to my už neumíme“" 89

Vznik řeči je pro Herdera, jak bylo před chvílí řečeno, přechodem od „Besonnenheit““ jakožto reflexivně zaměřené dispozice duševních sil člověka k „Besinnung“, jež je vlastním aktem tvorby řeči, tedy aktem vyčleňování a spojování. „Besonnenheit“ tedy přísluší jakémukoli stavu lidského vědomí včetně snění či některých stavů duševních chorob, nebot' i jim je vlastní určitý stupeň reflexivity, která umožňuje spojování předmětných obsahů lidské mysli: „Ne každé jednání lidské duše je bezprostředně důsledkem Besinnung, každé je ale důsledkem Besonnen-

\footnotetext{
84 Tamt., str. 720 n. (čes. překl. str. 29 n.), 728 (čes. překl. str. 35 n.).

85 Tamt., str. 721 (čes. překl. str. 30).

86 Tamt., str. 770 (čes. překl. str. 68).

87 Tamt., str. 771 (čes. překl. str. 68).

88 Srv. Herderovu předmluvu k Idejím (J. G. Herder, Ideen zur Philosophie der Geschichte der Menschheit, str. 17).
}

89 Týž, Frühe Schriften, str. 781 (čes. překl. str. 76). 
heit.“90 Aktem „Besinnung“ jsou pak obsahy lidského vědomí zvýslovněny, a to nejen uchopením prostřednictvím ,slova duše“, ale také prostřednictvím přiřazení smyslově vnímatelného znaku, jež vznik vnitřního slova doprovází. Přivedení do vědomí ve smyslu zřetelného uchopení je tak pro Herdera bytostně spjato se vznikem řeči po její vnitřní i vnější stránce. Všechny obsahy vědomí jakožto „stavy Besonnenheit“ jsou proto také ,„přiměřené řeči“ (sprachmäßig). ${ }^{91}$ Nejenže mohou být do řeči převedeny, ale člověk je celou svojí uzpůsobeností k řeči puzen k tomu, aby je do řeči převáděl, totiž aby se ,jeho řetěz myšlenek“, tedy obsahů vědomí, stal , ̌retězem slov“ “92

To podle Herdera současně neznamená, že by veškeré projevy vnitřního života člověka byly převoditelné do řeči. Právě zdroj tohoto vnitřního života, jednotící síla jakožto základ všech duševních mohutností člověka, která o sobě dává vědět v „temném“, vnitřně nerozlišeném pocitu, je nevyslovitelná. ${ }^{93}$ Člověka však dělá člověkem právě to, že se vše, co v sobě nachází, snaží vynést na světlo vědomí, vyslovit. ${ }^{94}$ Základ jeho lidství, který je zdrojem jeho identity jako živé bytosti se všemi jejími duševními mohutnostmi včetně rozumu, je právě jako zdroj jednoty pro řeč nepřístupný. Svoji identitu si však člověk současně buduje na rovině vědomí, a sice svoji identitu kulturní bytosti, která se k sobě vztahuje v procesu neustálé změny svého duševního, biologického i společenského života - a činí tak právě prostřednictvím řeči.

\section{Nejstarší zpráva lidského rodu}

V Pojednání o puvodu řeči Herder zdůrazňuje, že řeč je výtvorem bytostně lidským, a to i za předpokladu, že bychom z určitých důvodů přijali představu, že Bůh člověku tvorbu řeči ulehčuje obdobně, jako ji ulehčují dětem rodiče. Do takových hypotéz mu, jak tvrdí, s ohledem na filoso-

\footnotetext{
90 Tamt., str. 773 n. (čes. překl. str. 70).

91 Tamt.

92 Tamt.

93 Tamt.

94 Srv. Herderovy úvahy o „nejhlubší hlubině“ naší duše ve spise $O$ poznávání a pocit'ování lidské duše (viz J. G. Herder, Schriften zu Philosophie, Literatur, Kunst und Altertum, str. 345 n.). Herder píše o trojím způsobu, jímž z těchto temnot můžeme něco málo vynést na světlo: přísná a zcela upřímná sebereflexe, pozorování lékařů a přátel, proroctví a tušení básníků (tamt., str. 340-344).
} 
fický a nikoli theologický charakter jeho pojednání nic není. ${ }^{95}$ Naproti tomu ve svém o pár let mladším spise Nejstarší zpráva lidského rodu se sám do úvah o Božím podílu na vzniku lidské řeči pouští. V tomto spise považuje filosofické vysvětlení vzniku řeči za nedostatečné: „Člověk jako vlastní vynálezce řeči - at' filosof zkoumá, jak hluboce chce, dojde jen k tomu, že člověk řeč vynalézt mohl. Má k tomu schopnost, blízkou možnost a vlohu - na víc nikdy nepřijde, nebot' filosofie pojednává vždy jen o vnitřní možnosti a nezabývá se skutečností, důkazem existence (věcí tak odlišnou!)." ${ }^{96}$ Reviduje zde tedy Herder svůj původní postoj, jak sám naznačuje v souběžně vznikajícím spise $O$ poznávání a pocitování lidské duše (Vom Erkennen und Empfinden der menschlichen Seele),${ }^{97}$ nebo jej pouze doplňuje o další ohledy, pro něž v pojednání, které mělo ukázat vznik řeči z lidské přirozenosti, nebylo místo? Domnívám se, že platí druhá možnost, a v následující části ukážu, o jaká doplnění se jedná.

Spis Nejstarší zpráva lidského rodu sepsal Herder v letech 1774-1776. Nejstarší zprávou lidského rodu, z níž čerpají i jiné staroorientální texty, jsou podle něj první kapitoly biblické knihy Genesis, v níž člověk v dětství lidstva zaznamenal svoji zkušenost se světem, a sice přměřeně stupni svého kulturního vývoje i podmínkám, v nichž žil. ${ }^{98}$ Ačkoli Herder spojoval s tímto spisem velké ambice v oblasti theologie, historie a orientalistiky, ${ }^{99}$ jedná se o spis poměrně temný, mnohdy více básnický a rétorický než systematický. Proto $\mathrm{k}$ jeho výkladu přiberu ještě další spis, který Herder sepsal zhruba ve stejné době pod názvem O poznávání a pocit’ování lidské duše (1774-1778).

\subsection{Boží probouzení lidské řeči}

Čtenáře Nejstarší zprávy překvapí, že v ní Herder pod pojmem „Besinnung“, který byl v Pojednání představen jako aktualizace „Besonnenheit“" (a ani ta nemohla být podle Herdera chápána jako čirá potence),

\footnotetext{
95 J. G. Herder, Frühe Schriften, str. 727 n. (čes. př̀kl. str. 35).

96 Týž, Schriften zum Alten Testament, str. 277 n. Srv. také tamt., str. 519.

97 Týž, Schriften zu Philosophie, Literatur, Kunst und Altertum, str. 357.
}

98 Biblické texty tak nejsou pro Herdera, který se vymezuje proti učení o inspiraci, Božím slovem ve smyslu diktátu či vnuknutí, nýbrž způsobem, jak Boží zjevení pochopil člověk. Srv. úvodní poznámky textu $O$ prvních zprávách lidského rodu (Über die ersten Urkunden des menschlichen Geschlechts), za Herderova života nezveřejněného rozvrhu spisu o prvních kapitolách Genese, který předcházel sepsání Nejstarši zprávy (Tamt., str. 27-29).

99 Týž, Schriften zum Alten Testament, str. 1371 (komentár Rudolfa Smenda). 
rozumí „nic než schopnost, tj. receptivitu“, „chladnou, neúčinnou sílu“. ${ }^{100}$ Mohlo by se tak zdát, že Herder kritizuje své předchozí postoje. Při bližším čtení se však ukáže, že si zde Herder bere opět na mušku jen ty filosofy či theology, kteří se podle jeho mínění domnívají, že v člověku mohla být jakási mrtvá rozumová schopnost dříve, než se v něm začala rozvíjet řeč. ${ }^{101}$ Oproti Pojednání zde Herder nicméně zdůrazňuje, že lidská duše neaktualizuje svoji schopnost řeči sama ze sebe, nýbrž že se tak od prvního okamžiku lidské existence děje pod vedením „cizí síly“. ${ }^{102}$ Působení této cizí síly nazývá Herder poněkud překvapivě „Boží výukou“. Na otázku, jakým způsobem tato síla působí, Herder odpovídá: „Zvnějšku? Zvnitřku? Mysticky? Fyzicky? Jaká rozlišení! Cele! Božsky a lidsky! Prostřednictvím sil zvnitřku a potřeb zvnějšku." ${ }^{103} \mathrm{Co}$ to znamená?

Domnívám se, že důrazem na nutnost působení cizí síly pro aktualizaci lidské schopnosti řeči chce Herder říci, že lidská řeč vzniká jen prostřednictvím interakce člověka se světem, $\mathrm{k}$ níž pochopitelně dochází od prvního okamžiku lidské existence a která se děje prostřednictvím smyslů. Jak píše Herder ve spise O poznání a pocit’ování lidské duše, „ze sebe duše nesouká, neví, nepozdává nic, nýbrž co jí zevnitř i vně proudí z všehomíru a nač pokyne Boží ukazováček. "104 Právě v této souvislosti mluví Herder i v tomto spise o „škole Božství“, jíž se musí každá duše podrobit. Boží výuka tak spočívá v první řadě v tom, že se člověk učí používat své smysly, jimž okolní svět poskytuje látku. Rodič učí dítě mluvit tak, že mu poukazuje na svět kolem, a stejně tak to činí i Bůh jako stvořitel světa i lidské smyslovosti (slovo ,poukazovat“, ,,winken“, používá Herder opakovaně pro označení jak rodičovské, tak i Boží pomoci při tvorbě řeči). ${ }^{105}$

Jak v Nejstarší zprávě lidského rodu, ${ }^{106}$ tak ve spise $O$ poznávání a pocit’ování lidské duše spočívá proto Boží výuka v postupném oteví-

100 Tamt., str. 278.

101 K diskusi ohledně tohoto tématu viz G. Hassler - C. Neis, Lexikon sprachtheoretischer Grundbegriffe des 17. und 18. Jahrhunderts, 1, Berlin - New York 2009, str. $475 \mathrm{n}$.

102 J. G. Herder, Schriften zum Alten Testament, Frankfurt a. M. 1993, str. 278.

103 Tamt.

104 Týž, Schriften zu Philosophie, Literatur, Kunst und Altertum, str. 354.

105 Srv. např. týž, Schriften zum Alten Testament, Frankfurt a. M. 1993, str. 246, 279, týž, Schriften zu Philosophie, Literatur, Kunst und Altertum, str. 348, 354.

106 Srv. týž, Schriften zum Alten Testament, str. 250, 279 n. 
rání člověka světu prostřednictvím probouzení jeho smyslů. Naše smysly představují způsob, jakým pro nás náš Stvořitel svět, který na nás neustále působí množstvím nerozlišených vzruchů, utřídil, „, v nás a pro nás hláskoval“. 107 Jak již víme z Pojednání, leží základ veškerého poznání v pocitu, který se teprve krok za krokem diferencuje do jednotlivých smyslů, jež se člověk postupně učí používat. ${ }^{108}$ Právě v tomto postupném navykání na užívání smyslů vidí Herder v Nejstarší zprávě moudrost Boží stvořitelské pedagogiky, nebot' při jejich náhlém otevření by lidská duše byla zahlcena a svět by pro ni zůstal chaosem. ${ }^{109}$

Svět se člověku dává jako prostředkovaný jak jednotlivými smysly jakožto „branou“, tak také „médiem“, vnějším prostředím, které umožňuje těmto smyslům fungovat a které Herder nazývá „ukazováčkem božství pro naši duši“. ${ }^{110} \mathrm{~V}$ případě zraku, nejrozvinutějšího smyslu, je tímto médiem světlo, podle Nejstarší zprávy „,̌eč trůnu Božího“, která lidským očím postupně předestírá celé Boží stvoření, jak ho čtenáři malují úvodní biblické verše v $G n 1,1-2,4:, \ldots$ skrze médium této řeči se klene nebe a země: slunce přichází: vidîš vše, vše! sebe sama!"111 Také této ,کreči“, stejně jako později řeči ve vlastním slova smyslu, se člověk musí podle Herdera učit, ${ }^{112}$ nebot' schopnost vidět se rozvíjí postupně a leccos přebírá od jiných smyslů (zejména od hmatu). Řeč zraku je tak ,stejně široká, uměle naučená, nesčíslně kombinovaná, od věcí odlišná řeč“ ,113 jako je řeč prostředkovaná sluchem. To, že zde Herder mluví v souvislosti se světlem i zrakem o ,řeči“, má zdůraznit jejich zprostředkovatelskou funkci: prostřednictvím světla Bůh k člověku „mluvi“", ukazuje mu svět a učí jej v něm rozlišovat. Této řeči ${ }^{114}$ se zrak učí porozumět a přetváŕí ji ve svoji vlastní řeč, ve své vnitřní, strukturované vjemy.

107 Týž, Schriften zu Philosophie, Literatur, Kunst und Altertum, str. 348.

108 Svoji epistemologii Herder systematicky rozvíjí v souběžně vznikajícím spise O poznávání a pocitování lidské duše.

109 Srv. týž, Schriften zum Alten Testament, str. 250.

110 Týž, Schriften zu Philosophie, Literatur, Kunst und Altertum, str. 348.

111 Týž, Schriften zum Alten Testament, str. 252.

112 Herder vychází ze záznamů pozorování chirurga Williama Cheseldena, v té době populárních. Srv. týž, Frühe Schriften, str. 734 (čes. překl. str. 40). Dobovou diskusi i její filosofický význam představuje ve své Filosofii osvícenství Ernst Cassirer (E. Cassirer, Die Philosophie der Aufklärung, Hamburg 2007, str. 133 nn.).

113 J. G. Herder, Schriften zum Alten Testament, str. 252.

114 K označení vnějšího „média“ prostředkujícího mezi vnímanou věcí a příslušným smyslem jako řeč srv. také týž, Schriften zu Philosophie, Literatur, Kunst und Altertum, str. 357. 
Podle Herdera proto není náhodou, že pro autora první biblické zprávy o stvoření bylo prvním Božím stvořitelským činem stvoření světla a že pro staroorientálního člověka se světlo vůbec stalo symbolem božství a jeho působící moci. ${ }^{115}$ Stvoření světa Bohem pochopil člověk, jemuž ještě nebyla vlastní vyšší míra abstrakce, podle zkušenosti, kterou zažíval každodenně: jako postupné probouzení se nového dne, v němž světlo pozvolna proniká tmu a před našima očima odděluje zemi od nebe, rýsuje obrysy stromů a rostlin a probouzí ze spánku vše živé. Svítání se tomuto člověku v dětství lidstva stalo obrazem - a to obrazem „nejprostším, nejkrásnějším, nejsrozumitelnějším, nejuspořádanějším, nejvíce se opakujícím, nejpůsobivějším"116 - Božího působení ve světě a také první Boží ,־̌eči“ k člověku. Současně však platí, že svítání není jen obrazem, nýbrž také „,věcí samou“, 117 nebot' Boží stvořitelské jednání se v něm každé ráno opakuje a Bůh k člověku znovu promlouvá: „Nejstarší, nejvelkolepější zjevení Boží se ti ukazuje každé ráno jako skutečnost, velké Boží dílo v přírodě." $" 118$

Postupné otevírání lidských smyslů, které ostatně člověk probouzející se každé ráno ze spánku svým zpo̊sobem znovu zakouší, a velkolepý obraz stvoření světa, který před ty, kdo si přivstanou, maluje světlem Boží ruka, jsou dvojí stránkou téže Boží pedagogické metody, jíž Bůh člověka vychovává k řeči. ${ }^{119}$ Jak víme již z Pojednání, smyslové vnímání vždy doprovází pocit jakožto jeho subjektivní pól. Spolu se „živostí pocitu“, který podněcují smyslové vjemy, roste ,potřeba výrazu“. ${ }^{120}$ Člověk tak nucen prrírodním zákonem, jemuž podléhá vše živé - hledá pro obrazy, které mu před oči kreslí smyslovost ve spojení s představivostí, zvukový výraz. Takto jsou ,,smysly člověka harmonicky rozezvučeny a rozechvěny ke koncertu stvoření řeči“. ${ }^{121} \mathrm{~K}$ němu dochází v momentu probuzení rozumu.

Boží ruka maluje před lidskýma očima obrazy a jde o to, aby je člověk pochopil jako viditelný výraz toho, co je neviditelné - tedy toho, co se dává ne jeho smyslům, ale rozumu. Boží výuka tak není s otevřením smyslů u konce, nýbrž teprve na začátku. V člověku se musí probudit

\footnotetext{
115 Týž, Schriften zum Alten Testament, str. 206.

116 Tamt., str. 246.

117 Tamt., str. 250.

118 Tamt., str. 239.

119 Srv. tamt., str. 250 a 279 n.

120 Tamt., str. 279.

121 Tamt., str. 280.
} 
duch, aby mohl chápat to, co je duchovní, totiž slovo. Toto probuzení je možné jen prostřednictvím působení ducha. Když rodič učí dítě mluvit, pak nejen poukazuje, nýbrž pojmenovává a dítě se učí řeč tehdy, když ve zvucích, které rodič při mluvení vydává, rozpoznává výraz myšlenek, vnitřní slovo. Jen tehdy skutečně rozumí. Rodič tím, že mluví, učí dítě sdílet svět ducha, jehož jsou oba jakožto tvorové nadaní rozumem účastni. ${ }^{122}$ Reč je, jak píše Herder ve spise $O$ poznávání a pocit’ování lidské duše ve verzi z roku 1775, pro rozum stejným médiem, jako je jím světlo pro oko a zvuk pro ucho, a sice médiem, které mu strukturuje ${ }^{123}$ a otevírá duchovní svět. ${ }^{124}$ Prostřednictvím řeči se duše učí chápat samu sebe jako tu, která má v duchovním světě svůj zdroj a cíl.

Bůh proto, tak jako rodič, podle Nejstarší zprávy nejen ,ukazuje, poukazuje“ (zeiget, winket), nýbrž také „mluví a pojmenovává“ (spricht und nennet). Nečiní tak ale prostřednictvím artikulované řeči, nýbrž řeči obrazné. Ta je podle hypotéz, jež Herder zmiňuje ve své poněkud temné kapitole o hieroglyfu, Božím svatém písmu, formou řeči, která je vlastní „smyslovému“ člověku, jakým člověk byl v úsvitu svého lidství a jakým je dodnes ve svém raném dětství. ${ }^{125} \mathrm{~V}$ obrazné řeči - na rozdíl od konvenčně ustavených znaků - je výraz (at' už zvuk, či gesto) úzce spojen s tím, co vyjadřuje. ${ }^{126}$ To platí i pro Boží řeč k člověku: celý svět je výrazem Boží stvořitelské síly, která působí v nitru universa i v nitru každého jednotlivého tvora. ${ }^{127}$ Takto také působí na nitro člověka, duch probouzí ducha, síla sílu. Proto se člověku v dětství lidstva i dětství jednotlivce dává celá příroda jako oduševnělá, duch v ní pocit'uje ducha. ${ }^{128}$

122 Srv. týž, Schriften zu Philosophie, Literatur, Kunst und Altertum, str. 1141.

123 Srv. tamt., str. 1140.

124 Tamt.

125 J. G. Herder, Schriften zum Alten Testament, str. 267. S takovou hypotézou pracoval např. Condillac, podle nějž komunikace mezi lidmi probíhala nejprve pomocí „,̌eči jednání“ (langage d'action), jejímiž znaky byla gesta a zvuky jako výrazy emocí. Jejich pomocí člověk zobrazoval situaci, k níž chtěl odkázat. Teprve postupně byla tato řeč jednání nahrazena artikulovanou řečí, v níž se ze znaků ,přirozených“ staly znaky arbitrární a konvenčně ustavené. (É. B. Condillac, Esej o pưvodu lidského poznání, str. 136-141). Totéž platí podle obdobných hypotéz i pro počátky písma, jež mělo nejprve podobu obrazných znaků (srv. tamt., str. 267).

126 Tamt., str. 267.

127 Srv. tamt., str. 253-255. Srv. k tomu první kapitolu Idejí (J. G. Herder, Ideen zur Philosophie der Geschichte der Menschheit, str. 23 n.).

128 To, že člověk Boha v přírodě nejprve ,pocit’uje“, není náhodné. Vzhledem $\mathrm{k}$ tomu, že všechny duševní mohutnosti člověka jsou podle Herdera odlišným pro- 
Obrazy, které tak Bůh každého probouzejícího se jitra staví lidem před oči v úsvitu jejich dějin, jsou obrazy mocnými, mluvícími. V tomto smyslu nebesa „vypravuji““ o Boží slávě. ${ }^{129}$ Jednotlivě i ve svém sledu jsou tyto obrazy znameními Božího jednání, jednotlivými Božími „slovy“ v mediu obrazné řeči. Tato „slova“, rozlišená ve zprávě o stvoření do jednotlivých dní, vyplývají, jak se Herder snaží ukázat, jedno z druhého a tvoří ve svých vzájemných vztazích vnitřně propojený celek, jednotu v mnohosti, jediný Boží hieroglyf vepsaný do stvoření. ${ }^{130}$

Boží „hlas“, jímž Bůh pojmenovává, a tím probouzí lidskou schopnost řeči, tak není přístupný uším člověka, nýbrž ozývá se v jeho nitru a má podobu pocitu, který volá po výrazu. Jak píše Herder ve spise $O$ poznávání a pocit’ování lidské duše ve verzi z roku 1775, člověk ,,pocit'uje na sobě Boží řeč a pojmenovává svojí řečí“. ${ }^{131}$ Obdobně to vyjadřuje v Nejstarší zprávě: ,Bůh promluvil k člověku a člověk promluvil. ... Bůh byl jeho slovem a toto všemocné slovo se posléze sdílelo celé príírodě, aby k němu [člověku] mluvila, aby si v něm zněla zpět. ... Tak všechno mluvilo opakujíc po Bohu (so sprach Alles Gott nach) a probudilo lidskou řeč prostřednictvím vylitého soucitu (durch ergossenes Mitgefühl)." ${ }^{132}$ Lidské pojmenovávání zviŕrat, o němž bude řeč dále, je tak odpovědí na Boží slovo, které k člověku zní z celé přírody a rozechvívá jeho nitro.

Schopnost člověka slyšet takto bezprostředně Boží slovo v přírodě, jež se odrazila ve zrodu lidské řeči, omezuje Herder na úsvit lidské kultury, jehož ozvuk nacházíme i nyní ve vývoji dítěte. Tehdy ještě, jak to známe z Pojednání, mohutnosti lidské duše tvořily větší jednotu. I rozum se rodí z pocitu a nepřestává z něj čerpat. Jednota a nerozlišenost pocitu je výrazem jednoty síly, která konstituuje lidskou existenci. Prostřednictvím pocitu nás nejen svět, ale i Bůh zpravuje o své existenci, síla působí na sílu.

jevem jedné síly působící v lidském nitru, je nediferencovaný pocit základem nejen smyslového vnímání, ale také rozumu, protože je temným a neurčitým základem poznání jako takového. Srv. týž, Schriften zum Alten Testament, str. 250 n.

129 Srv. tamt., str. 277 a 249, kde Herder cituje $\check{Z} 19$.

130 Týž, Schriften zum Alten Testament, str. 271. Vzájemné vyplývání „slov stvoření“ tvořících současně jeden celek označuje Herder jako „hříčku“, mechanickou pomůcku pro pamět' člověka v dětství lidstva (tamt., str. 267). Mnohem později v $M e$ takritice však toto téma rozvíjí na filosofické rovině při demonstraci vzájemného vyplývání rozumových pojmů, které v mnohém připomíná pozdější Hegelovu dialektiku (srv. týž, Schriften zu Literatur und Philosophie, str. 397 nn.).

131 Týž, Schriften zum Alten Testament, str. 1141.

132 Týž, Schriften zu Philosophie, Literatur, Kunst und Altertum, str. 519 n. 
Odstup člověka vůči světu, který jej bezprostředně obklopuje, je v rané fázi rozvoje jeho lidství menší a pocity, které v něm vyvolává působení jeho okolí, silnější. Tyto pocity jej zpravují o síle působící ve všem, co se mu smyslově dává. Tato síla není nikdy jako taková předmětem jeho smyslového vnímání, ale současně ji člověk „,cítí“. „Neviditelné“ se mu dává spolu s ,viditelným“. ${ }^{133} \mathrm{~V}$ silách přírody, jimž je člověk probouzející se smyslovosti i ducha vystaven, se mu současně dává pocit’ovat Bůh ve své tvůrčí moci: „Všechny přírodní síly, jeho andělé! Všechny události světa, jeho zázraky a činy!" 134 Herder ve svém textu nikde výslovně nevysvětluje, jak člověk dochází k tomu, že síly, které na něj působí, jsou projevem jediné božské síly (kde se tedy bere tento prvotní monotheismus). Je však možno říci, že skutečnost, že člověk v dětství lidstva pocit'uje $\mathrm{v}$ rozličných projevech přírody, $\mathrm{v}$ nichž na něj působí „tvořící Elohim“, 135 jednu sílu, je výrazem a odrazem jednoty síly, jejíž působení pocit'uje v sobě samém. Přesvědčení o existenci jediného Boha působícího ve všem není tak podle Herdera výsledkem dokazování, nýbrž zakládá se v jistotě, která je jistotou pocitu (bez níž by pak veškeré dokazování bylo jen prázdnou hrou se slovy). ${ }^{136}$ Pro nás, kteří jsme této původní jednotě vzdáleni, ,oslabeni abstrakcí, odlišujeme a rozdělujeme smysly, rozplétáme náš pocit pamětí a zaměstnáními rozumu do tenkých vláken, která už nic necítí plně a čistě - pochopitelně tím musí být tento velký smysl pro ,Boha, toho Všudypř́ítomného ve světě“ oslaben a otupen“. 137

Z toho také vposled vyplývá jedinečnost Božího zjevení „Adamovi“. Př́roda zůstává i nadále projevem Boží moci, způsobem Božího sebesdílení. Boží príitomnost v ní však první lidé pocitovali mnohem bezprostředněji než lidé v pozdějších stádiích vývoje lidstva, a proto se i my jen těžko vcit'ujeme do ,pravěku stvořitelského náboženství“ (Urzeit der Schöpfungsreligion), ,když byl Adam, stál tam, viděl Boha všude, sebe v něm, sebe cítil jako jeho obraz - svaté momenty Prvního zjevení“. 138 Proto se lidská řeč mohla zrodit právě tehdy, kdy duch působící v přírodě podněcoval lidského ducha.

133 Srv. tamt., str. 253.

134 Tamt., str. 253.

135 Tamt., str. 253. Srv. tamt., str. 200. Herder si zde hraje s hebrejským označením Boha v Gn 1,1, které je v hebrejštině mluvnickým plurálem: jediný Bůh působí v množství přírodních sil.

136 Srv. tamt., str. 251.

137 Tamt., str. 253.

138 Tamt., str. 254. 


\subsection{Boží řeč jako předobraz a pravzor lidské řeči, člověk jako Boží obraz}

Bůh podle Herdera nejen učí člověka mluvit tak jako rodič dítě tím, že v něm probouzí rozum, ale Boží řeč je také ,„pravzorem a předobrazem vši řeči lidské“. 139 Člověk se jejím prostřednictvím a na ní učí „symbolizovat", tedy rozpoznávat ducha v tom, co před ním kreslí jeho smyslovost a představivost, a současně dávat této neviditelné myšlence opět smyslový výraz: „malovat a utvářet pojmy, jména, naučení, neviditelnou duši“ “. ${ }^{140}$ Předobrazem a pravzorem je však Boží řeč pro řeč lidskou ještě v jednom smyslu, který s právě řečeným úzce souvisí. Svým slovem, jež je zároveň činem, Bůh tvoří svět a světu vládne, celá přríroda je projevem jeho jednotící a organizující moci. Lidská řeč tuto Boží moc, jakkoli nedokonale, napodobuje. Vládnout nad přírodou je úkol, který člověku ukládá jeho určení být Božím obrazem, ${ }^{141}$ a právě prostř̌ednictvím řeči naplňuje člověk svoje určení.

V řadě obrazů, které člověku staví před oči jeho probouzející se duše i probouzející se ráno a v nichž on cítí jednat Boží mocné slovo, je tím posledním obrazem on sám. Podle Pojednání je základním určením člověka, jež ho odlišuje od zvîrat a jež umožňuje vznik řeči, „Besinnung“, reflexe. Tento sebevztah, jenž se projevuje nejprve na rovině citu a dovršuje se na rovině vědomí, ${ }^{142}$ je tím, co z člověka podle Nejstarší zprávy činí obraz jeho Stvořitele: „... suma jeho existence - Boží obraz, suma jeho povinnosti - být činný (sich regen)! panovat, vládnout (walten), tak jako on prostě cítí vládnout všude slovem a činem Stvořitele, když jím proudí pohyb (Rege) a slovo Boží, jaké dětské tóny nejabstraktnějších idejí lidské duše!"143 Prostřednictvím reflexe v sobě člověk cítí působit sílu, jejímž zdrojem není on sám. Rozpoznává-li člověk sebe jako činného, působícího, pak se současně rozpoznává jako obraz té síly, jež proniká jím samým i celou prrírodou a tuto prrírodu tvoří a oživuje. Idea

139 Tamt., str. 255.

140 Tamt., str. 269.

141 Tamt., str. 278 (srv. Gn 1,27n). Srv. týž, Frühe Schriften, str. 809 (čes. překl. str. 97), dále nap̌̌. týž, Schriften zu Philosophie, Literatur, Kunst und Altertum, str. 355 .

142 Ve spise O poznávání a pocit’ování lidské duše jej Herder ztotožňuje s apercepcí: „Všechny vjemy (Empfindungen), které vystupují k určité jasnosti (vnitřní stav je přitom nepojmenovatelný), se stávají apercepcí, myšlenkou; duše rozpoznává, že pocit'uje“ (týž, Schriften zum Alten Testament, str. 354).

143 Týž, Schriften zu Philosophie, Literatur, Kunst und Altertum, str. 280. 
vyvolaná v lidské mysli působením této síly, která je neproniknutelná, neuchopitelná, nezpředmětnitelná a nepojmenovatelná, je tak tou nejabstraktnější ideou lidské duše.

Zrod vnitřního slova, jímž se v člověku podle Pojednání rodí řeč, je přerodem smyslového vjemu v myšlenku, ${ }^{144}$ přetvořením vnějšího světa ve svět vnitřní. Ve spise $O$ poznávání a pocit’ování lidské duše ve verzi z roku 1775 tuto moc rozumu popisuje Herder takto: „Co duše činí jiného, než že nepřetržitě ničí tělo, celý vnější všehomír, bez odporu překonává čas a prostor, vytváří z nich svět, který je zcela neviditelný, její bytnosti a jejího druhu. "145 Současně je to svět, který duše může sdílet prostřednictvím vnějšího znaku s těmi, kdo jsou schopni být tohoto světa účastni. ${ }^{146}$ Ve tvorbě duchovního světa se tak projevuje tvůrčí moc duše, která je odrazem stvořitelské moci Boží. Na rozdíl od Boha však člověk netvoří svým slovem z ničeho, nýbrž přetváŕí to, co mu přináší jeho smyslovost a co jeho rozum nachází k rozumění. Přesto je tento vnitřní a současně s druhými sdílený svět vlastním výtvorem člověka, produktem organizující síly jeho duše, která to, co nachází, přizpůsobuje sama sobě a vtiskuje mu svůj obraz. Tato činnost, při níž duše buduje svůj vnitřní svět, je současně obrácená navenek, vůči světu vnějšímu. Podle spisu $O$ poznávání a pocitování lidské duše je rozpoznání „Jsem dcera Boží, jsem jeho obraz“ doprovázeno Božím „Učiňme!““,147 jímž duše „chce a vládne“. ${ }^{148}$ Vytčení charakteristických znaků, strukturace světa prostřednictvím myšlení, jehož vnějším výrazem je řeč, je způsobem, jak světu vládnout a jak jej přetvářet - a sice tu část světa, již Bůh člověku k vládě svěřuje.

V Nejstarší zprávě se Herder drží biblického vyprávění, podle nějž Bůh pojmenovává den a noc, nebe, zemi a moře. ${ }^{149}$ Podle Herdera je v orientálním chápání akt pojmenování totožný s dovršením či zakon-

144 V pozdějším spise $O$ obraze, básnictví a bajce (1787) Herder tvrdí, že činnost lidské duše není ničím jiným než neustálou „,metaschematizací“, neustálým „,překládáním“ mezi naprosto odlišnými věcmi: předmětem, o němž nás zpravují naše smysly, obrazem naší představivosti, myšlenkou a zvukovým výrazem této myšlenky (tamt., str. 636).

145 Tamt., str. 1141.

146 Tamt.

147 Srv. týž, Schriften zu Philosophie, Literatur, Kunst und Altertum, str. 230 a Gn 1,26 .

148 Týž, Schriften zum Alten Testament, str. 355.

149 Týž, Schriften zu Philosophie, Literatur, Kunst und Altertum, str. 255. 
čením díla. ${ }^{150}$ Bůh tak svým slovem dává světu základní časovou a prostorovou strukturu, kterou předestírá probouzející se lidské duši, a tím v ní pokládá ,základy lidského poznání - Boží slova“.151 Boží řeči se člověk učí na těchto ,velkých, poklidných, setrvávajících, př́ijemných výtvorech“, 152 které se mu stávají znameními Boží velebnosti a vlády a probouzejí v něm sílu jeho ducha, jeho rozum. Hemžení živých tvorů na zemi Bůh přenechává $\mathrm{k}$ pojmenování člověku, ${ }^{153}$ který dává - jak to známe už z Pojednání - zvukům přírody podobu slov. ${ }^{154}$ Tímto lidským pojmenováním tak příroda, dalo by se říci, dochází završení svého stvoření a v člověku se prostřednictvím reflexe obrací zpět ke svému Stvořiteli. Vesmír s myriádami hvězd a sluncí rííí svými zákony Bủh, příroda zde na zemi je však Bohem svěřena člověku, ,pozemskému bohu“, 155 aby ji prostřednictvím řeči a v nápodobě Božího stvořitelského jednání přetvořil ve vlastní kulturní svět.

\subsection{Vznik řeči z touhy a lásky}

Podle Pojednání poskytla člověku první charakteristické znaky i jejich vnější zvukové výrazy sama příroda ve svých zvucích. V Nejstarší zprávě Herder spojuje toto tvrzení s biblickým vyprávěním z Gn 2,19, zmíněným již v předchozím oddíle, podle nějž Bủh přivádí před člověka zvířata, aby viděl, jak je pojmenuje. Toto pojmenování je projevem lidské vlády nad přírodou, jež vyplývá z určení člověka být Božím obrazem. Herder však do svého výkladu zapojuje také kontext této krátké zmínky o prvních lidských slovech, jímž je příběh o stvoření ženy. Člověk zvirirata nejen pojmenovává, ale hledá - a nenachází - mezi nimi pomoc sobě rovnou; ${ }^{156}$ hledá tedy podle Herdera tu, v níž by rozpoznal svoje druhé já a v lásce $\mathrm{k}$ níž by mohl současně milovat sám sebe. Obojí spolu podle Herdera nejen v biblickém výkladu, ale také věcně souvisí.

Podle první části Pojednání je důležitým impulsem pro vznik řeči potřeba. Vnější potřeby podněcují člověka k tomu, aby ovládnul přírodu prostřednictvím řeči v zájmu svého přežití, a tím nahradil svoji nedo-

150 Srv. tamt., str. 212.

151 Tamt., str. 255.

152 Tamt., str. 279.

153 Srv. Gn 2,19.

154 Srv. J. G. Herder, Schriften zu Philosophie, Literatur, Kunst und Altertum, str. $527 \mathrm{n}$.

155 Tamt., str. 262.

156 Tamt., str. 523-532. 
statečnou smyslovou a pudovou vybavenost. Uzpůsobením k řeči tak příroda kompenzuje člověku to, čím jinak obdařila ostatní živé tvory. ${ }^{157}$ To ovšem neznamená, že by řeč byla pouhým nástrojem, kterým prríroda člověka vybavila v zájmu jeho přežití a který mu umožňuje př́rodu ovládat a vlastnit. ${ }^{158}$ Řeč je v Pojednání, stejně jako v Nejstarší zprávě prostředkem k uskutečnění lidství člověka. Jeho telos a telos zvírete se liší. Také v Nejstarší zprávě Herder význam potřeb pro vznik řeči zmiňuje, 159 ve výkladu ke zmíněnému biblickému oddílu se však hlavním impulsem pro zrod artikulované lidské řeči stává touha poznávat a milovat.

Artikulovaná lidská řeč se rodí ze sepětí člověka s přírodou $\mathrm{v}$ „soucitu“ (Mitgefühl), ${ }^{160}$ svazku, jímž Bůh spojuje ve svém stvoření vše živé a jenž podle Pojednání dal vzniknout neartikulované řeči zvîrat. V Nejstarší zprávě je základem, bez nějž by nemohla vzniknout ani řeč lidská. Člověk je ve svém tělesném i duševním ústrojenství souhrnem a završením vší stvořené přírody a současně ve své reflexivitě Božím obrazem. ${ }^{161}$ Díky tomu, jak Herder píše ve spisu O poznávání a pocitování lidské duše, je člověk ,sensorium svého Boha ve všem, co ve stvoření žije, v té míře, nakolik je s ním toto živé příbuzné“. ${ }^{162} \mathrm{~V}$ „ušlechtilém všeobecném pocitu“ se spojují a navzájem podmiňují sebecit, vcítění do druhého i pocit’ování Boha. Pocit je výrazem jednoty, a proto základem veškerého poznání. ${ }^{163}$ Ze stejné jednoty vyrůstá i řeč, a proto spolu poznání a řeč souvisejí.

Jak podle Pojednání, tak podle Nejstarší zprávy je lidská řeč odpovědí na to, co $\mathrm{k}$ člověku - na rovině citu - promlouvá v prrírodě. Příroda působí na jeho nitro a člověk takto vzbuzenému pocitu, který doprovází každý vjem, dává výraz. Jak již bylo několikrát řečeno, nejedná se o pouhou mechanickou ozvěnu, zvuky př́rody člověk transformuje na vyšší, rozumovou rovinu - dává zvířatům jméno, a proto jim vládne. K tomu si však podle Herdera půjčuje „slovo jejich úst“ a tato výpůjčka je projevem „vcítění se“ do „přirozenosti““ toho, co je pojmenováváno,

157 Srv. týž, Frühe Schriften, str. 716 (čes. překl. str. 26), 775 n. (čes. překl. str. 71 n.).

158 Srv. tamt., str. 776 n. (čes. překl. str. 72 ), 788 (čes. překl. str. 81).

159 Srv. J. G. Herder, Schriften zu Philosophie, Literatur, Kunst und Altertum, str. 278.

160 Tamt., str. 519 n. Srv. také tamt., str. 528.

161 Srv. tamt., str. 298, srv. dále týž, Schriften zum Alten Testament, str. 361.

162 Tamt., str. 361. Srv. také tamt., str. 363.

163 Srv. tamt., str. 361. 
a uznáním jeho svébytnosti. ${ }^{164}$ Zvuky, jež vydávají zvîrata, jsou projevem jejich oduševnělosti, síly, jež z nich činí živou bytost a jež je vposled vyjádřením Boží stvořitelské moci v nekonečné rozmanitosti forem. Jména, v něž člověk tyto zvuky proměňuje, jsou výrazem toho, že ve zvîreti tuto Boží moc rozpoznává a uznává. ${ }^{165}$ Člověk, který právě vzešel z lůna prrírody, s níž je spojen poutem soucitu, a jemuž jeho Stvořitel vdechl dech reflexe a rozumu, ${ }^{166}$ se obrací ke světu, aby v něm hledal a spatřoval to, co je mu vlastní, totiž ducha, a tomuto vlastnímu dává ve jméně výraz. Prvotní je touha svět poznat, nikoli tyransky ovládnout a řeč vzniká právě z této touhy. Rajský, prvotní stav je stavem harmonie mezi člověkem a př́rodou, ${ }^{167}$ nikoli bojem o přežití a nadvládu. To se odráží i na podobě prvotní, rajské a nevinné řeči:

„Touha po sobě rovném splétala jemnou osnovu první řeči: jak bratrskou, něžnou a lidskou musela být. ... Jméno každé živé bytosti bylo v tomto věnci přátelství dobrým svědectvím dobroty Stvořitele v této př́rodě, vypuštěná (ausgeschüttete) slabika ze srdce prvorozeného bratra, současně svazek i osvědčení vztahu k jeho srdci, foedus, pignus amoris." 168

164 J. G. Herder, Schriften zu Philosophie, Literatur, Kunst und Altertum, str. 528.

165 Poznání, které je současně přitakáním a přivlastněním („Anerkennen“), a pojmenování spojuje Herder už v Pojednání (srv. týž, Frühe Schriften, str. 722 n. [čes. překl. str. 31] a 733 [čes. překl. str. 39]). Později v Metakritice se pojem „Anerkennen“ stává pro Herdera důležitým při kritice Kanta. Původní význam tohoto slova je podle Herdera „počít, rodit, být zrozen“, což je etymologie, která vychází z německého užití tohoto slova při překladu hebrejského j-1-d (,poznat“ i „,mít pohlavní styk“, srv. Gn 4,1). „Anerkennen“ či „Erkennen“ znamená rozpoznání toho, co je společné mně i poznávanému: „Pro sebe je rozpoznávám a volám: jsou mé povahy, mého rodu („Ich erkenne sie mir an, und sage laut: sie sind meiner Natur, meines Geschlechts“, týž, Schriften zu Literatur und Philosophie, str. 391).

166 Srv. J. G. Herder, Schriften zu Philosophie, Literatur, Kunst und Altertum, str. $502 \mathrm{n}$.

167 Tamt., str. 528.

168 Tamt., str. 529. Zpětně viděno, tyto motivy jsou přítomny už v Pojednání. I podle něj člověku poskytuje první charakteristické znaky ve svých zvucích sama příroda, je mu tak první „učitelkou řeči“ (týž, Frühe Schriften, str. 753 [čes. překl. str. 41]). Tím, že příroda prostřednictvím svých zvuků působí na nitro člověka, dává se mu jako oduševnělá, člověk v ní nachází sám sebe. Teprve s postupující systematizující a abstrahující prací rozumu, která ruší bezprostřední pouto mezi člověkem a přírodou na rovině pocitu, dochází k jejich vzájemnému odcizení. 
Tuto původní povahu řeči zachycují báje o dobách, kdy člověk rozuměl řeči zvir̃at (její odraz pak také nacházíme ve schopnosti malých dětí mluvit se vším okolo nich). ${ }^{169}$

Vůči ostatním živým bytostem člověk pocit’uje soucit podle míry podobnosti, nejvyšší míru soucitu však cítí ve vztahu k druhému člověku. Podle biblického vyprávění proto člověk uspokojuje svoji touhu po nalezení sobě rovného teprve při pohledu na ženu, svoje „druhé já“. 170 V ní člověk ve svrchované míre miluje sebe a současně toho, jehož jsou oba obrazem, totiž Boha. Pojmenování se mění v uznání rovnosti, které člověk při pohledu na svoji družku vyzpívá v oslavné písni podle $G n$ 2,23. Jakkoli Herder vztah řeči a druhého na tomto místě ve svém výkladu biblického příběhu netematizuje a namísto toho se věnuje úvahám o manželství, lze říci, že právě v druhém člověku se společenství soucitu završuje ve společenství řeči, které je možné jen mezi sobě rovnými, rozumem nadanými bytostmi. (O potřebě tohoto společenství píše Herder v Nejstarší zprávě tehdy, když si všímá zvyku osamělého člověka mluvit se vším, co jej obklopuje, a co mu tak, byt' nedostatečně, nahrazuje př́ítomnost druhých.) ${ }^{171}$

Tím, že Herder umíst'uje počátek lidské řeči v souladu s biblickým textem do rajského stavu, vymezuje se proti Rousseauovi, pro nějž byl - přinejmenším v Rozpravě o pưvodu nerovnosti - vznik řeči jedním z prvních projevů odcizení člověka a přírody (jejichž vzájemnou harmonii založenou v soucitu ovšem předpokládají oba). Pro Herdera lidská řeč vyrůstá z pouta lásky mezi člověkem a přírodou, jakkoli je současně také projevem lidského určení k vládě nad přírodou založené v rozumu. Ambivalentní povaha řeči, která je dána tím, že řeč je nejen projevem vzájemnosti, ale též odstupu, se projeví až s objevem lži, tedy zneužitím řeči, které hraje podle Herdera významnou roli v př́běhu o pádu člověka. ${ }^{172} \mathrm{~V}$ něm se slovo osamostatňuje a vyprazdňuje a stává se nástrojem svodu a moci. V důsledku toho se také otcovská a láskyplná vláda člověka nad prrírodou, jež se odrážela v prvotní řeči, promění ve vládu tyranskou. Nikoli už láska, ale potřeba se stává jediným způsobem vztahování se člověka $\mathrm{k}$ přírodě. Prostřednictvím řeči člověk přírodu ovládá, vítězí nad ní v boji o přežití, ale současně jí přestává

169 Srv. týž, Schriften zu Philosophie, Literatur, Kunst und Altertum, str. 529, $567 \mathrm{n}$.

170 Srv. tamt., str. 535.

171 Srv. tamt., str. 568.

172 Srv. tamt., str. 572-577. 
naslouchat a rozumět. To pak také znamená, že v ní přestává vidět a cítit Boha. ${ }^{173}$ Jak je zřejmé z jiných Herderových děl, zejména z Fragmentů (1767-1768), stejně jako z Pojednání, tento vývoj jde ruku v ruce s abstrahující a systematizující prací rozumu, jemuž hrozí, že bez kontaktu se smyslovostí a představivostí vytvoří do sebe uzavřený a současně bezobsažný svět. Jakkoli si Herder uvědomuje ambivalenci řeči a z ní vyrůstající lidské kultury, zůstává pro něj nicméně řeč a kultura tím, čím člověk jedině uskutečňuje svoje lidství a naplňuje svoje určení být Božím obrazem. Proto patří řeč již do ráje, a není teprve způsobem, jak je ráj opouštěn.

\section{Závěrem}

Jakkoli Herder v Nejstarší zprávě připouští nezbytnost Božího podílu na vzniku lidské řeči, nelze v tomto spise nalézt nic, co by popíralo cokoli z toho, co napsal ve svém Pojednání o pưvodu řeči. Stále je to člověk, kdo vytváří artikulovanou lidskou řeč. Fysikotheologická argumentace jeho protivníků, ${ }^{174}$ podle níž krása, uspořádanost a dokonalost lidské řeči svědčí o jejím božském původu, ${ }^{175}$ Herdera ani nyní nepřesvědčuje. Současně však svoji argumentaci z Pojednání doplňuje o podmínku, za níž jedině mohla lidská řeč vzniknout. Člověk se vztahuje ke světu prostř̌ednictvím řeči jen proto, že svět k němu „mluví“, že se dává jeho rozumění a probouzí v něm potřebu výrazu. Na pozadí výkladu biblických textů Herder - bohužel někdy spíše v hádankách - rozvíjí úvahy o vztahu řeči a světa, které v Pojednání chybí a k nimž se mnohem později detailněji vrátí ve spise Metakritika ke Kritice čistého rozumu. Lidský vynález řeči Herder v Nejstarš́ zprávě zasazuje do širšího metafyzického rámce a tvrdí, že lidská řeč v sobě specifickým způsobem odráží ontologické principy vládnoucí universu, jak jim rozumí na pozadí své spinozovsko-leibnizovské metafyziky, podle níž je veškerý svět výrazem jedné pořádající síly projevující se v rozmanitosti dílčích, vzájemně interagujících organických sil.

V Pojednání jsou podmínkami vzniku řeči vyčlenění charakteristického znaku a souběžné přiřazení znaku vnějšího. Mohlo by se zdát, že

173 Srv. tamt., str. 253 n.

174 Srv. D. K. Kim, Sprachtheorie im 18. Jahrhundert. Herder, Condillac und Süßmilch, St. Ingbert 2002, str. 85-88.

175 Srv. J. P. Süßmilch, Versuch eines Beweises, str. 15-17. 
obojí je vůči tomu, k čemu se řeč vztahuje, totiž ke světu, do značné míry nahodilé. ${ }^{176}$ Charakteristickým znakem se stane to, co nejsnáze upoutá pozornost a nejlépe se pamatuje. Vnější znak je v počátcích řeči v některých prrípadech přebírán ze zvuků přírody, v mnoha jiných je zvukovým vyjádřením pocitu. Řeč sice není ve svých počátcích ustavena podle Herdera konvenčně, ale přesto se v ní odráží pouze subjektivní postoj mluvčího, který toho jen málo vypovídá o věci samé. V dalším vývoji řeči spojeném s její fixací v tradici se i tato původní vazba řeči na prožívaný svět pomalu vytrácí. Různost řečí, která vznikla z vázanosti jednotlivých národů na odlišné přírodní podmínky a je dále posilována odlišností kulturního vývoje spojeného s budováním skupinové identity, ${ }^{177}$ se zdá tuto nahodilost potvrzovat.

Tato nahodilost má však svoje meze, které Herder v Nejstarší zprávě vysvětluje pomocí svého výkladu o „Boží výuce“. Jak podle Pojednání, tak podle Nejstarší zprávy člověk řeč vytváří proto, že patří k jeho teleologicky pochopené přirozenosti: Jejím prostřednictvím uskutečňuje svoje lidství. Aby k tomu však podle Nejstarší zprávy mohlo dojít, musí na člověka působit „cizí síla“, Boží duch musí prostřednictvím přírody působit na lidského ducha. Toto působení člověk v přírodě pocit'uje a dává mu v řeči výraz. Řeč tedy není ve vztahu ke světu nahodilá, nýbrž zachycuje a vyjadřuje jeho vnitřní dynamiku. To je také důvod, proč podle Herdera sloveso předchází ve vývoji řeči substantivu a poetické stádium vývoje řeči stádiu prozaickému a filosofickému. ${ }^{178}$ Řeč není ustavována vhledem do statické racionální struktury universa, nýbrž odráží dynamiku Božího působení ve světě, jeho vše prostupující a vše organizující moc. Řeč je zajisté orgánem rozumu, ovšem rozumu činného, organizujícího a tvůrčího. Systematická struktura řeči, kterou zachycují gramatiky a která podle Herdera hypostazuje do metafyziky, je jen jakousi sedlinou této organizující činnosti rozumu. Svět ducha je stejně tak dynamický, organický a rozmanitý jako svět přírody, jejž zrcadlí a současně završuje, nebot' obojímu vládne jedna božská síla. ${ }^{179}$

176 Srv. J. G. Herder, Ideen zur Philosophie der Geschichte der Menschheit, str. $348 \mathrm{n}$.

177 Srv. týž, Frühe Schriften, str. 791-799 (čes. překl. str. 83-89).

178 Srv. pozn. 78.

179 Tento příspěvek byl podpořen programem Univerzitní výzkumná centra UK č. UNCE/HUM/016. 


\section{ZUSAMMENFASSUNG}

Der vorliegende Beitrag widmet sich der Darstellung von Herders frühen Sprachphilosophie auf dem Hintergrund der Frage nach dem menschlichen oder göttlichen Ursprung der Sprache, die insbesondere die deutsche Debatte in den sechziger Jahren des achtzehnten Jahrhunderts bestimmt hat. Im Fokus der Aufmerksamkeit steht die Interpretation von zwei Werken, in denen Herder die Frage nach dem Ursprung der Sprache scheinbar unterschiedlich beantwortet: Abhandlung über den Ursprung der Sprache und Älteste Urkunde des Menschengeschlechts. Während in der Abhandlung Herder auf dem menschlichen Ursprung der Sprache beharrt, wird in der Ältesten Urkunde die Notwendigkeit des ,göttlichen Unterrichts“ für ihren Ursprung angenommen. Es stellt sich also die Frage, ob Herder seine ursprüngliche Haltung revidiert hat. Wie jedoch der Artikel zeigt, handelt sich nicht um eine Revision, sondern um eine Ergänzung der Thesen der Abhandlung um metaphysische Voraussetzungen, die einen unabdingbaren Rahmen der Sprachphilosophie Herders bilden.

\section{SUMMARY}

The article aims to present Herder's early philosophy of language against the background of the question regarding the human or divine origin of language, which influenced mainly the German discussion in the 1760s. It focuses on the interpretation of two writings in which Herder answers the question of the origin of speech in a seemingly different way: A Treatise on the Origin of Language and The Oldest Document of the Human Race. While in the Treatise Herder insists on the human origin of language, in The Oldest Document he admits the need for "God's teaching" for its origin. The question therefore arises as to whether Herder has revised his original position. However, we demonstrate that The Oldest Document is not a revision, but a supplement to the theses contained in the Treatise by metaphysical assumptions, which form an indispensable framework for Herder's philosophy of language. 